\title{
Synthesis and Reactivity of Fluorinated Triaryl Aluminum Complexes
}

\author{
Darren M. C. Ould, ${ }^{\ddagger}$ Jamie L. Carden, ${ }^{\ddagger}$ Rowan Page, and Rebecca L. Melen*
}

Cite This: Inorg. Chem. 2020, 59, 14891-14898

Read Online

ABSTRACT: The addition of the Grignard 3,4,5- $\mathrm{Ar}^{\mathrm{F}} \mathrm{MgBr}$ to aluminum(III) chloride in ether generates the novel triarylalane $\mathrm{Al}\left(3,4,5-\mathrm{Ar}^{\mathrm{F}}\right)_{3} \cdot \mathrm{OEt}_{2}$. Attempts to synthesize this alane via transmetalation from the parent borane with trimethylaluminum gave a dimeric structure with bridging methyl groups, a product of partial transmetalation. On the other hand, the novel alane $\operatorname{Al}\left(2,3,4-\mathrm{Ar}^{\mathrm{F}}\right)_{3}$ was synthesized from the parent borane and trimethylaluminum. Interestingly, the solid-state structure of $\mathrm{Al}\left(2,3,4-\mathrm{Ar}^{\mathrm{F}}\right)_{3}$ shows an extended chain structure resulting from neighboring $\mathrm{Al} \cdots \mathrm{F}$ contacts. $\mathrm{Al}\left(3,4,5-\mathrm{Ar}^{\mathrm{F}}\right)_{3} \cdot \mathrm{OEt}_{2}$ was then found to be an effective catalyst for the hydroboration of carbonyls, imines, and alkynes with pinacolborane.

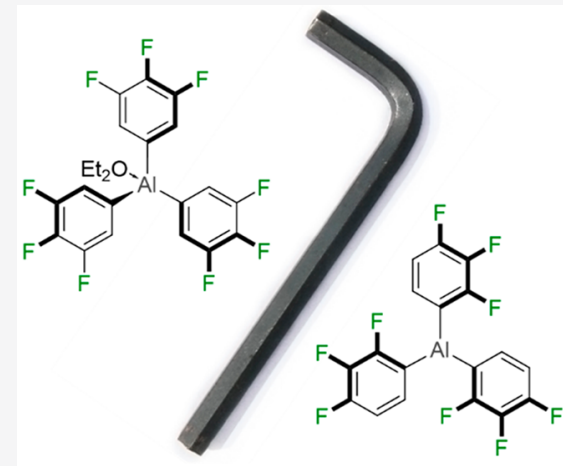

\section{INTRODUCTION}

Since the ground-breaking discovery of frustrated Lewis pairs (FLPs) in 2006, ${ }^{1}$ the use of triarylboranes to aid organic transformations has rapidly grown in the past 20 years. ${ }^{2,3}$ Interestingly though, the use of the heavier aluminum analogues has received notably less attention. Pohlmann and Brinckmann successfully prepared tris(pentafluorophenyl)alane $\left[\mathrm{Al}\left(\mathrm{C}_{6} \mathrm{~F}_{5}\right)_{3}\right]$ as the $\mathrm{Et}_{2} \mathrm{O}$ adduct in $1965,{ }^{4}$ but no further reports were made until the analogous THF adduct was generated in $1995 .^{5}$ Since these reports there have been disputes in the literature regarding the Lewis acidity of $\mathrm{Al}\left(\mathrm{C}_{6} \mathrm{~F}_{5}\right)_{3}$ and whether it is a stronger Lewis acid than $\mathrm{B}\left(\mathrm{C}_{6} \mathrm{~F}_{5}\right)_{3}$, with claims by Lee et al. and Stahl et al. that the latter is the much stronger Lewis acid. ${ }^{6,7}$ On the other hand, a number of experimental and computational observations contradict this view and support $\mathrm{Al}\left(\mathrm{C}_{6} \mathrm{~F}_{5}\right)_{3}$ being the stronger Lewis acid. ${ }^{8-10}$ A possible explanation for the disagreement in the Lewis acidity of $\mathrm{Al}\left(\mathrm{C}_{6} \mathrm{~F}_{5}\right)_{3}$ is its tendency to form strong adducts with Lewis bases, which in turn quenches its reactivity. In fact, it was not until 2016 that the unsolvated structure of $\mathrm{Al}\left(\mathrm{C}_{6} \mathrm{~F}_{5}\right)_{3}$ was reported by $\mathrm{Chen}$ et al., who achieved this by transmetalation from $\mathrm{B}\left(\mathrm{C}_{6} \mathrm{~F}_{5}\right)_{3}$ with $\mathrm{AlEt}_{3}$ in hexane. ${ }^{11}$

Since its first isolation as a THF adduct, $\mathrm{Al}\left(\mathrm{C}_{6} \mathrm{~F}_{5}\right)_{3}$ has seen a number of uses, including the modification of methylalumoxane, ${ }^{6}$ transfer polymerization, ${ }^{12}$ and methide abstraction. ${ }^{8}$ Lately, $\mathrm{Al}\left(\mathrm{C}_{6} \mathrm{~F}_{5}\right)_{3}$ has been applied extensively toward FLP chemistry, to undergo $\mathrm{H}_{2}$ activation and hydride transfer to alkenes, ${ }^{13} \mathrm{C}-\mathrm{H}$ activation, ${ }^{14,15}$ and the activation of $\mathrm{CO}_{2}{ }^{16}$ However, a note of caution has always been present when working with $\mathrm{Al}\left(\mathrm{C}_{6} \mathrm{~F}_{5}\right)_{3}$; Pohlmann and Brinckmann found that attempts to sublime the crude mixture of $\mathrm{AlCl}_{3}$ and the
Grignard $\mathrm{C}_{6} \mathrm{~F}_{5} \mathrm{MgBr}$ in ether led to an explosion, as did heating a solution of $\mathrm{AlEt}_{3}$ with $\mathrm{B}\left(\mathrm{C}_{6} \mathrm{~F}_{5}\right)_{3}$ to $70{ }^{\circ} \mathrm{C} .{ }^{4}$ Chen proposed that the thermal and shock sensitive nature of unsolvated $\mathrm{Al}\left(\mathrm{C}_{6} \mathrm{~F}_{5}\right)_{3}$ derives from the ability of the compound to readily decompose to form strong $\mathrm{Al}-\mathrm{F}$ bonds and explosive tetrafluorobenzyne. This was observed in the solid-state structure of the compound which exists as a dimer [Al$\left.\left(\mathrm{C}_{6} \mathrm{~F}_{5}\right)_{3}\right]_{2}$ that displayed close intermolecular $\mathrm{Al} \cdots \mathrm{F}$ interactions between the aluminum center of one molecule and an ortho-fluorine atom of a second molecule. ${ }^{11}$

Literature reports of fluorinated triarylalanes with alternate fluorine substitution patterns to $\mathrm{Al}\left(\mathrm{C}_{6} \mathrm{~F}_{5}\right)_{3}$ are surprisingly sparse (Figure 1). One example includes the use of $\mathrm{Al}(2,3,5,6$ $\left.\mathrm{Ar}^{\mathrm{F}}\right)_{3}$ for FLP assisted $\mathrm{H}_{2}$ and olefin activation. ${ }^{17}$ Additionally, $\mathrm{Al}\left(4-\mathrm{Ar}^{\mathrm{F}}\right)_{3}$ has been used in optimizations toward sequential retro-ene arylation and [3,3]-sigmatropic rearrangement/ nucleophilic arylation reactions. ${ }^{18,19}$

Given our group's recent interest in the borane $\mathrm{B}(3,4,5$ $\left.\mathrm{Ar}^{\mathrm{F}}\right)_{3}{ }^{20-22}$ we were inspired to synthesize its aluminum analogue, in part due to the absence of ortho-positioned fluorine atoms. We propose that the alane counterpart would possess similar Lewis acidity as $\mathrm{Al}\left(\mathrm{C}_{6} \mathrm{~F}_{5}\right)_{3}$, but devoid of orthofluorine atoms, it may offer more stability.

Received: April 13, 2020

Published: September 1, 2020 


\section{Previous work:}<smiles>CCO[Al](c1c(F)c(F)c(F)c(F)c1F)(c1c(F)c(F)c(F)c(F)c1F)c1c(F)c(F)c(F)c(F)c1F</smiles>

$\mathrm{Al}\left(\mathrm{C}_{6} \mathrm{~F}_{5}\right)_{3} \cdot \mathrm{Et}_{2} \mathrm{O}$

Pohlmann and Brinckmann<smiles>Fc1cc(F)c(F)c([Al](Cl)(c2c(F)c(F)cc(F)c2F)c2c(F)c(F)cc(F)c2F)c1F</smiles>

$\mathrm{Al}\left(2,3,5,6-\mathrm{F}_{4} \mathrm{C}_{6} \mathrm{H}\right)_{3} \cdot$ tol Stephan<smiles>O=C(c1c(F)c(F)c(F)c(F)c1F)N(c1c(F)c(F)c(F)c(F)c1F)c1c(F)c(F)c(F)c(F)c1F</smiles>

$\mathrm{Al}\left(\mathrm{C}_{6} \mathrm{~F}_{5}\right)_{3} \cdot$ tol Park<smiles>Fc1c(F)c(F)c([Al](c2c(F)c(F)c(F)c(F)c2F)c2c(F)c(F)c(F)c(F)c2F)c(F)c1F</smiles>
Chen<smiles>Fc1c(F)c(F)c([Al](c2c(F)c(F)c(F)c(F)c2F)(c2c(F)c(F)c(F)c(F)c2F)c2c(F)c(F)c(F)c(F)c2F)c(F)c1F</smiles>

$\mathrm{Al}\left(\mathrm{C}_{6} \mathrm{~F}_{5}\right)_{3} \cdot \mathrm{THF}$ Roesky<smiles>Fc1ccc([Al](c2ccc(F)cc2)c2ccc(F)cc2)cc1</smiles>

$\mathrm{Al}\left(4-\mathrm{FC}_{6} \mathrm{H}\right)_{3}$ Miyata

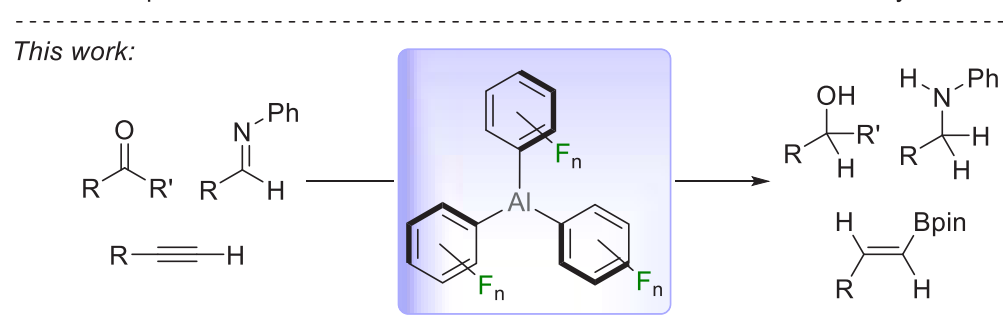

Figure 1. Previously reported triarylalanes and this work.

Scheme 1. Synthesis of $\mu_{2}$-Dimethyl-bis [(3,4,5-trifluorophenyl)methyl-alane] from Partial Transmetallation<smiles>Fc1cc(B(c2cc(F)c(F)c(F)c2)c2cc(F)c(F)c(F)c2)cc(F)c1F</smiles>

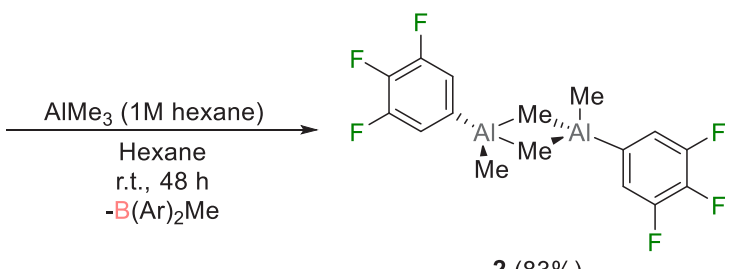

$2(83 \%)$

Herein, we report the synthesis of several new alanes bearing fluorinated aryl rings and explore their structural properties. In addition, we explore their reactivity as a catalyst for the reduction of carbonyls, imines, and alkynes with the terminal reductant pinacolborane (HBpin).

\section{RESULTS AND DISCUSSION}

Early attempts to synthesize unsolvated tris(3,4,5trifluorophenyl)alane, $\mathrm{Al}\left(3,4,5-\mathrm{Ar}^{\mathrm{F}}\right)_{3}$, procedurally mirrored that of the previously reported unsolvated tris(perfluorophenyl)alane, $\mathrm{Al}\left(\mathrm{C}_{6} \mathrm{~F}_{5}\right)_{3}$, by Chen. ${ }^{11}$ Trimethylaluminum ( $1 \mathrm{M}$ in hexane) was added to $\mathrm{B}\left(3,4,5-\mathrm{Ar}^{\mathrm{F}}\right)_{3}(\mathbf{1})$ in hexane and left undisturbed for 2 days at room temperature. After this time crystals suitable for single-crystal X-ray diffraction had formed. The ${ }^{1} \mathrm{H}$ NMR spectrum of these crystals showed the expected aromatic signal at $\delta=6.87 \mathrm{ppm}$, but more significantly, an upfield singlet resonance at $\delta=$ $-0.39 \mathrm{ppm}$ was also present, with an integral ratio of $6: 2$ compared to the aromatic signal. Unexpectedly, structural refinement of the single-crystal data revealed that an aluminum dimer with bridging methyl groups and only one aryl group had formed (2), as opposed to the expected $\mathrm{Al}\left(3,4,5-\mathrm{Ar}^{\mathrm{F}}\right)_{3}$ triarylalane (Scheme 1). Given the equivalence of the terminal and bridging methyl groups in the compound, variable temperature ${ }^{1} \mathrm{H}$ NMR studies were performed. At $-80{ }^{\circ} \mathrm{C}$, the signals were found to resolve; however, results were inconclusive due to the reduced solubility of the species (see the Supporting Information).

The formation of $\mathbf{2}$ can be rationalized as a partial transmetalation reaction in which only one of the aryl groups from the starting borane has transferred, leaving two methyl groups from the trimethylaluminum still bonded. Repeating this transmetalation reaction at $40{ }^{\circ} \mathrm{C}$ still failed to give complete transfer of all three aryl groups to the aluminum center. Recent work by Stammler et al. on the bonding of $\mathrm{Al}_{2} \mathrm{Me}_{6}$ suggests that the bridging $\mathrm{CH}_{3}$ groups are assignable to two highly ionic $2 \mathrm{e}, 3 \mathrm{c}$ bonds with tetra-coordinate aluminum atoms. ${ }^{23}$ Similar dimeric species containing $2 \mathrm{e}, 3 \mathrm{c}$ bonds have 
been recorded from incomplete transmetalation of $\mathrm{B}\left(\mathrm{C}_{6} \mathrm{~F}_{5}\right)_{3}$ with $\mathrm{AlMe}_{3}{ }^{24}$

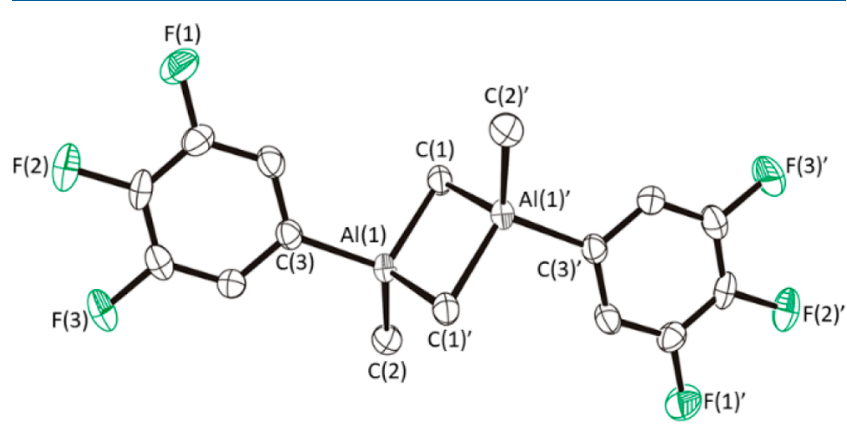

Figure 2. Solid-state structure of $\mu_{2}$-dimethyl-bis[ $[(3,4,5$ trifluorophenyl)methyl-alane]. $\mathrm{H}$ atoms are omitted for clarity, and thermal ellipsoids are drawn at $50 \%$ probability.

Inspection of the solid-state structure of dimer 2 (Figure 2), which crystallizes in the triclinic space group $P \overline{1}$ with half a molecule in the asymmetric unit, revealed an $\mathrm{Al}(1) \cdots \mathrm{Al}\left(1^{\prime}\right)$ distance of 2.599(2) A. The bridging $\mathrm{Al}(1)-\mathrm{C}(1)$ bond was measured at 2.096(3) $\AA$, which is appreciably longer than the terminal $\mathrm{Al}(1)-\mathrm{C}(2)$ bond $(1.940(5) \AA)$. Interestingly, the $\mathrm{Al}(1)-\mathrm{C}(1)^{\prime}$ bridging bond length is longer than that of $\mathrm{Al}(1)-\mathrm{C}(1)$, measuring 2.134(3) $\AA$ and showing asymmetry in the dimer.

Measuring the bond angles around the aluminum center shows a $\mathrm{C}(2)-\mathrm{Al}(1)-\mathrm{C}(3)$ bond angle of $116.7(2)^{\circ}$, which is approximately $7^{\circ}$ lower than what is seen in $\mathrm{Al}_{2} \mathrm{Me}_{6}$. However, the $\mathrm{C}(1)-\mathrm{Al}(1)-\mathrm{C}(3)$ bond angle measures $106.5(1)^{\circ}$, which is comparable to that seen in $\mathrm{Al}_{2} \mathrm{Me}_{6}$. ${ }^{23}$

Although the transmetalation reaction did not give the desired 3,4,5- $\mathrm{Ar}^{\mathrm{F}}$ derived triarylalane, use of the novel $\mathrm{B}(2,3,4$ $\left.\mathrm{Ar}^{\mathrm{F}}\right)_{3}$ triarylborane (3, Figure 3, top) under the same conditions gave the expected unsolvated $\mathrm{Al}\left(2,3,4-\mathrm{Ar}^{\mathrm{F}}\right)_{3}$ alane (4) (Scheme 2) from the transmetalation reaction. Initially 4 was characterized using single-crystal X-ray diffraction, where it crystallizes in the orthorhombic $\mathrm{Pbca}$ space group, with one molecule present in the asymmetric unit (Figure 3, bottom). 4 could also be isolated as the THF adduct.

The solid-state configuration revealed the expected triarylalane structure, with the three 2,3,4-fluorinated aryl groups coordinated to the aluminum center. The geometry of $\mathrm{Al}\left(2,3,4-\mathrm{Ar}^{\mathrm{F}}\right)_{3}$ is similar to that of the parent borane, in that it is near trigonal planar, with $\mathrm{C}-\mathrm{Al}-\mathrm{C}$ bond angles measuring $115.0(2)^{\circ}, 121.5(2)^{\circ}$, and $115.9(2)^{\circ}$.

Analysis of the unit cell of 4 shows short Al $\cdots \mathrm{F}$ contacts, where the ortho-fluorine from one aryl group interacts with the aluminum center on a neighboring triarylalane. This donation from the ortho-fluorine creates a long chain arrangement in the packing structure of 4, where this bridging ortho-fluoride interaction is repeated (Figure 4). This $\mathrm{Al} \cdots \mathrm{F}$ interaction is strong, as seen by the Al $\cdots \mathrm{F}$ distance of 2.034(3) $\AA$. As a consequence of this specific chain formation, $\pi$-stacking between two of the aryl groups in neighboring alanes (one from each triarylalane) is permitted, with the two aryl plane distances measuring 3.401(5) A. The long chain arrangement of 4 is different to that seen in the unsolvated $\mathrm{Al}\left(\mathrm{C}_{6} \mathrm{~F}_{5}\right)_{3}$, where Chen reports a dimeric packing structure of the alane through ortho-fluorine atoms. ${ }^{11}$

Due to difficulties in the synthesis of $\mathrm{Al}\left(3,4,5-\mathrm{Ar}^{\mathrm{F}}\right)_{3}$ by transmetalation, a Grignard method was instead adopted from
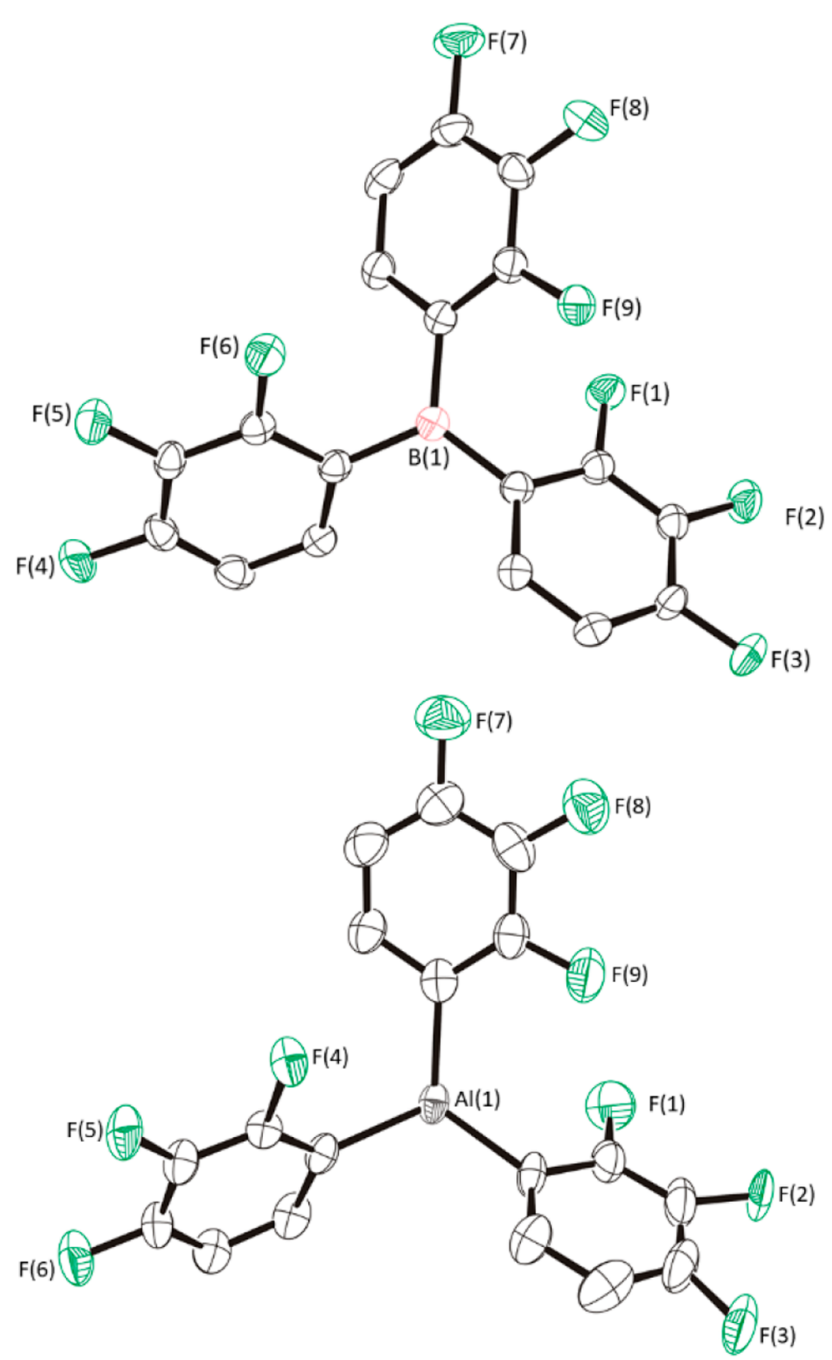

Figure 3. Top: Solid-state structure of $\mathrm{B}\left(2,3,4-\mathrm{Ar}^{\mathrm{F}}\right)_{3}$. Bottom: Solidstate structure of $\mathrm{Al}\left(2,3,4-\mathrm{Ar}^{\mathrm{F}}\right)_{3} . \mathrm{H}$ atoms are omitted for clarity, and thermal ellipsoids are drawn at $50 \%$ probability.

1-bromo-3,4,5-trifluorobenzene and aluminum trichloride in ether solvent (Scheme 3). Upon workup, the ${ }^{1} \mathrm{H}$ NMR spectrum in $\mathrm{C}_{6} \mathrm{D}_{6}$ showed the expected aryl proton signal at $\delta$ $=6.99 \mathrm{ppm}$, but in addition it also showed stoichiometric ether present, with signals appearing at $\delta=3.00 \mathrm{ppm}$ and $\delta=0.28$ ppm. The latter is much more upfield compared to free uncoordinated ether. The ${ }^{19} \mathrm{~F}$ NMR spectrum shows the expected two signals in a $2: 1$ ratio at $\delta=-153.5 \mathrm{ppm}$ and $\delta=$ -160.7 ppm, respectively.

The solid-state structure of triarylalane 5 was obtained, and structural refinement found that it crystallizes in the triclinic $P \overline{1}$ space group with one molecule in the asymmetric unit. The solid-state structure also showed that the triarylalane exists as an etherate adduct, $\mathrm{Al}\left(3,4,5-\mathrm{Ar}^{\mathrm{F}}\right)_{3} \cdot \mathrm{OEt}_{2}$ (5) (Figure 5), as was suggested from the ${ }^{1} \mathrm{H}$ NMR spectrum. The coordination of ether means that unlike in 4,5 adopts a near tetrahedral geometry, with $\mathrm{O}-\mathrm{Al}-\mathrm{C}$ bond angles of $104.1(2)^{\circ}, 104.5(2)^{\circ}$, and $107.1(2)^{\circ}$.

Density functional theory (DFT) was then employed to better understand the structural properties possessed by these triarylalanes. Initially, geometry optimization and vibrational frequency calculations on the unsolvated structures were 
Scheme 2. Synthesis of $\mathrm{Al}\left(2,3,4-\mathrm{Ar}^{\mathrm{F}}\right)_{3}$ from Transmetallation

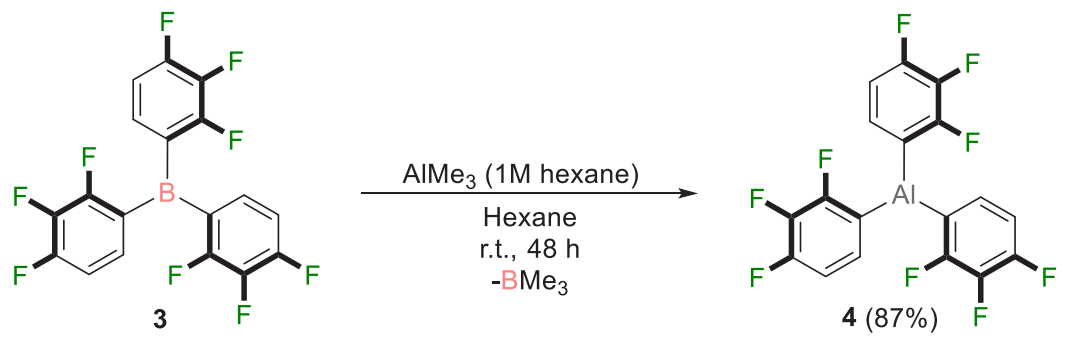

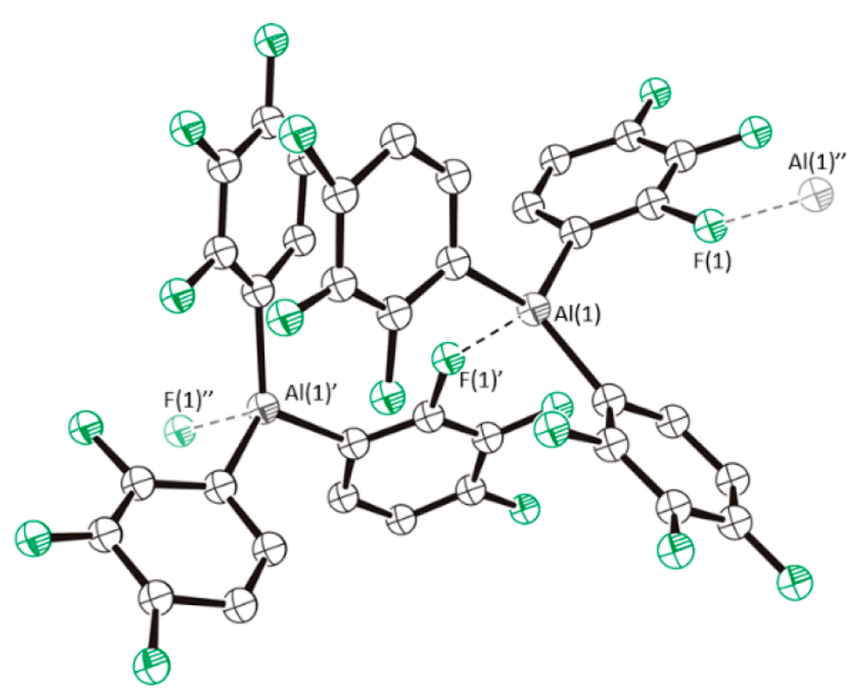

Figure 4. Chain arrangement of $\mathrm{Al}\left(2,3,4-\mathrm{Ar}^{\mathrm{F}}\right)_{3}$ molecules in the unit cell; dashed bond represents neighboring $\mathrm{Al} \cdots \mathrm{F}$ contacts. $\mathrm{H}$ atoms are omitted for clarity.

undertaken using the theory M06-2X/cc-pVDZ. Natural bond orbital (NBO) analysis showed a significantly greater buildup of positive charge at the aluminum center than at the boron center in the analogous triarylboranes, which led us to believe these triarylalanes would show enhanced Lewis acidic behavior (see the Supporting Information). To quantify this, fluoride ion affinity (FIA) calculations were performed (Table 1).

As the fluoride ion is relatively small and highly basic, it will interact with most Lewis acids. ${ }^{25}$ At this level of theory, the well-known strong Lewis acid $\mathrm{B}\left(\mathrm{C}_{6} \mathrm{~F}_{5}\right)_{3}$ had a FIA of $459 \mathrm{~kJ}$ $\mathrm{mol}^{-1}$, similar to that previously reported. ${ }^{8,26,27}$ Proceeding with this, the triarylalanes $\mathrm{Al}\left(3,4,5-\mathrm{Ar}^{\mathrm{F}}\right)_{3}$ and $\mathrm{Al}\left(2,3,4-\mathrm{Ar}^{\mathrm{F}}\right)_{3}$ were found to have a FIA of 511 and $501 \mathrm{~kJ} \mathrm{~mol}^{-1}$, respectively, whereas their triarylborane counterparts $B(3,4,5$ $\left.\operatorname{Ar}^{\mathrm{F}}\right)_{3}$ and $\mathrm{B}\left(2,3,4-\mathrm{Ar}^{\mathrm{F}}\right)_{3}$ produced values of 427 and $404 \mathrm{~kJ}$ $\mathrm{mol}^{-1}$ accordingly. What is interesting about these values is

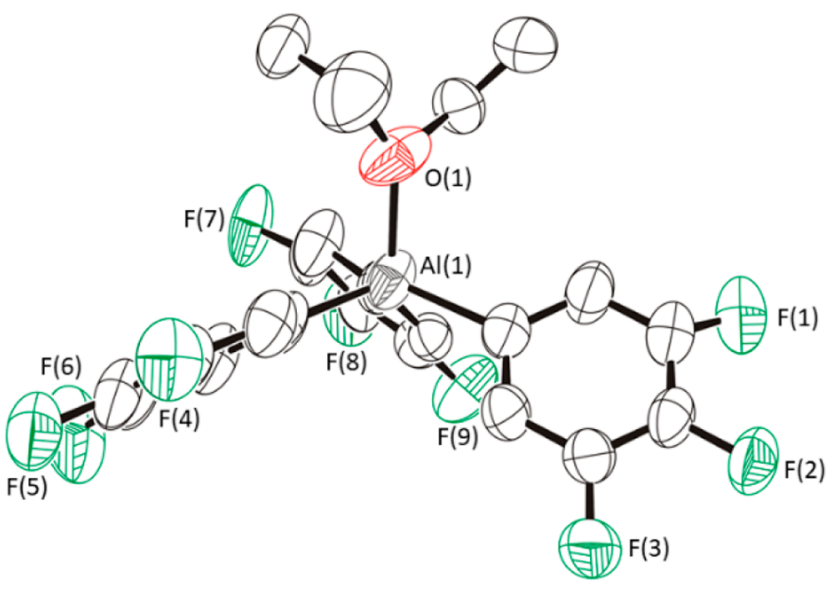

Figure 5. Solid-state structure of $\mathrm{Al}\left(3,4,5-\mathrm{Ar}^{\mathrm{F}}\right)_{3} \cdot \mathrm{OEt}_{2} . \mathrm{H}$ atoms are omitted for clarity, and thermal ellipsoids are drawn at 50\% probability.

Table 1. Fluoride Ion Affinity Values

\begin{tabular}{lcc}
\multicolumn{1}{c}{ structure } & FIA $\left(\mathrm{kJ} \mathrm{mol}^{-1}\right)$ & relative FIA (\%) \\
$\mathrm{Al}\left(3,4,5-\mathrm{Ar}^{\mathrm{F}}\right)_{3}$ & 511 & 95 \\
$\mathrm{Al}\left(2,3,4-\mathrm{Ar}^{\mathrm{F}}\right)_{3}$ & 501 & 93 \\
$\mathrm{~B}\left(3,4,5-\mathrm{Ar}^{\mathrm{F}}\right)_{3}$ & 427 & 79 \\
$\mathrm{~B}\left(2,3,4-\mathrm{Ar}^{\mathrm{F}}\right)_{3}$ & 404 & 75 \\
$\mathrm{Al}\left(\mathrm{C}_{6} \mathrm{~F}_{5}\right)_{3}$ & 541 & 100 \\
$\mathrm{~B}\left(\mathrm{C}_{6} \mathrm{~F}_{5}\right)_{3}$ & 459 & 85 \\
\hline
\end{tabular}

that the triarylalanes appear to be approximately $15 \%$ more Lewis acidic than their triarylborane counterparts.

With $\mathrm{Al}\left(3,4,5-\mathrm{Ar}^{\mathrm{F}}\right)_{3} \cdot \mathrm{OEt}_{2}$ (5) in hand, its reactivity was probed by using it in the first reported example of triarylalaneassisted hydroboration reduction catalysis. For the optimization conditions, the hydroboration of acetophenone with HBpin was performed (Table 2). Initial use of $5 \mathrm{~mol} \%$ catalytic loading at room temperature proved kinetically slow, as did increasing the catalytic loading to $10 \mathrm{~mol} \% \mathbf{5}$. However,

Scheme 3. Synthesis of $\mathrm{Al}\left(3,4,5-\mathrm{Ar}^{\mathrm{F}}\right)_{3} \cdot \mathrm{OEt}_{2}$ via the Grignard Reaction

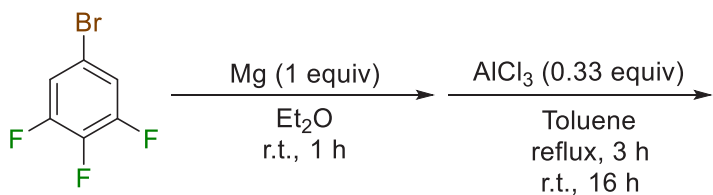


Table 2. Optimization of Hydroboration Catalysis ${ }^{a}$

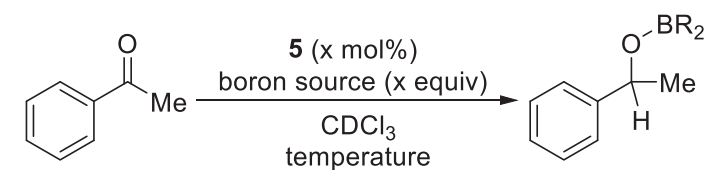

$\begin{array}{ccccrr}\text { entry } & \begin{array}{c}\text { catalyst loading } \\ (\text { mol \%) }\end{array} & \begin{array}{c}T \\ \left({ }^{\circ} \mathrm{C}\right)\end{array} & \begin{array}{c}\text { borane source } \\ \text { (equiv) }\end{array} & \begin{array}{c}\text { yield } \\ \end{array} & \begin{array}{c}\text { time } \\ (\mathrm{h})\end{array} \\ 1 & 0 & 25 & \text { HBpin }(1.2) & <5 \% & 24 \\ 2 & 5 & 25 & \text { HBpin }(1.2) & <5 \% & 24 \\ 3 & 10 & 25 & \text { HBpin }(1.2) & <5 \% & 24 \\ 4 & 0 & 70 & \text { HBpin }(1.2) & <5 \% & 24 \\ 5 & 5 & 70 & \text { HBpin }(1.2) & 68 \% & 24 \\ 6 & 10 & 70 & \text { HBpin }(1.2) & >95 \% & 6 \\ 7^{c} & 10 & 70 & \text { HBpin }(1.2) & >95 \% & 6 \\ 8 & 10 & 70 & \text { HBpin }(1.0) & 85 \% & 24 \\ 9 & 10 & 70 & \text { HBcat }(1.2) & <5 \% & 24 \\ 10 & 10 & 70 & 9-B B N(1.2) & <5 \% & 24\end{array}$

${ }^{a}$ Acetophenone $(0.2 \mathrm{mmol}, 24 \mathrm{mg}) .{ }^{b}$ Conversion determined by ${ }^{1} \mathrm{H}$ NMR spectroscopy with internal mesitylene standard $(0.1 \mathrm{mmol}, 14$ $\mathrm{mL}) .{ }^{c}$ Benzene- $d^{6}$ solvent instead of $\mathrm{CDCl}_{3}$.

use of $10 \mathrm{~mol} \% \mathbf{5}$ at $70{ }^{\circ} \mathrm{C}$ gave quantitative conversion to the boronate ester in $6 \mathrm{~h}$. Switching the solvent from $\mathrm{CDCl}_{3}$ to benzene- $\mathrm{d}^{6}$ gave no deleterious effect, but moving from 1.2 equiv to stoichiometric HBpin did. Testing alternative borane sources found that neither 9-BBN nor HBcat were reactive toward the hydroboration of acetophenone.

Proceeding with the optimum conditions of $10 \mathrm{~mol} \%$ precatalyst 5, 1.2 equiv of $\mathrm{HBpin}$, and $70{ }^{\circ} \mathrm{C}$ in $\mathrm{CDCl}_{3}$, the substrate scope was expanded to determine the versatility and suitability of $\mathbf{5}$ as a catalyst for hydroboration reduction (Scheme 4).

First, aldehydes were readily reduced within $2 \mathrm{~h}$ and obtained as alcohols in high isolated yields up to $97 \%(6 a-d)$, with little discrepancy in tolerance between electron withdrawing, electron donating, and bulky substrates. Likewise, ketones and aldimines were readily reduced, with smooth conversion to the product and excellent isolated yields upon hydrolysis workup $(7 \mathbf{a}-\mathbf{d}, \mathbf{8} \mathbf{a}-\mathbf{d})$. We then investigated the reduction of $\mathrm{C}-\mathrm{C}$ multiple bonds. Preliminary studies with the olefins styrene, alpha-methylstyrene, 4-chlorostyrene, and 4(trifluoromethyl)styrene were promising, showing good conversions $(>90 \%)$ in $24-48 \mathrm{~h}$. Finally, terminal alkynes were also hydroborated efficiently into their corresponding boronate esters $(\mathbf{9 a}-\mathbf{d})$, with bulky, along with electronwithdrawing and electron-donating, substituents being tolerated. The internal alkynes diphenylacetylene and 1-phenyl-1propyne showed no conversion under these conditions. Note boronate esters $\mathbf{9 a}-\mathbf{d}$ were stable even under basic conditions.

Scheme 4. Hydroboration of Aldehydes, Ketones, Aldimines, and Alkynes with HBpin using $5^{a}$

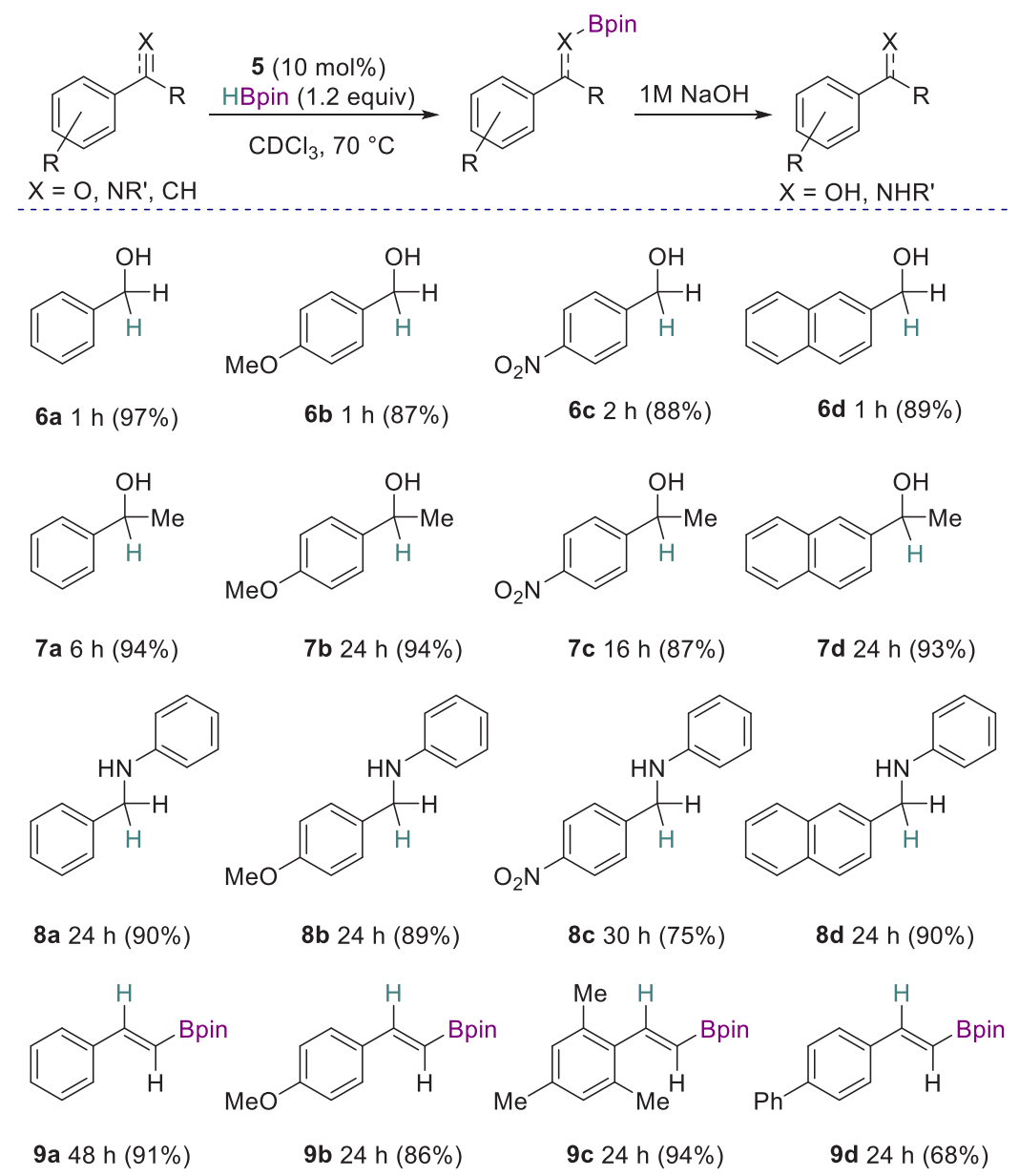

${ }^{a_{\text {Time }}}$ taken to reach quantitative conversion by ${ }^{1} \mathrm{H}$ NMR spectroscopy. Isolated yields in parentheses. 


\section{EXPERIMENTAL SECTION}

General Experimental. Unless stated otherwise, all reactions were carried out under an atmosphere of dinitrogen using standard Schlenk and glovebox techniques. With the exception of THF, $\mathrm{Et}_{2} \mathrm{O}$, and deuterated solvents, all solvents used were dried by passing them through an alumina column incorporated into an MB SPS- 800 solvent purification system, degassed, and finally stored in an ampule fitted with a Teflon valve under a dinitrogen atmosphere. THF was dried over molten potassium for 3 days and distilled over argon, whereas $\mathrm{Et}_{2} \mathrm{O}$ was dried over sodium wire and benzophenone before being distilled over argon. Deuterated solvents were dried over calcium hydride, distilled, freeze-pump-thawed degassed, and stored over 3 $\AA$ molecular sieves in a glovebox. Starting materials were purchased from commercial suppliers and used as received. ${ }^{1} \mathrm{H},{ }^{13} \mathrm{C}\left\{{ }^{1} \mathrm{H}\right\},{ }^{19} \mathrm{~F}$, and ${ }^{11} \mathrm{~B}$ NMR spectra were recorded on a Bruker Avance 400 or 500 $\mathrm{MHz}$ spectrometer. Chemical shifts are expressed as parts per million (ppm, $\delta$ ) and are referenced to $\mathrm{CDCl}_{3}(7.26 / 77.16 \mathrm{ppm})$ or $\mathrm{C}_{6} \mathrm{D}_{6}$ $(7.16 / 128.06 \mathrm{ppm})$ as internal standards. Multinuclear NMR spectra were referenced to $\mathrm{BF}_{3} \cdot \mathrm{Et}_{2} \mathrm{O} / \mathrm{CDCl}_{3}\left({ }^{11} \mathrm{~B}\right)$ and $\mathrm{CFCl}_{3}\left({ }^{19} \mathrm{~F}\right)$. The description of signals includes $\mathrm{s}=$ singlet, $\mathrm{d}=$ doublet, $\mathrm{t}=$ triplet, $\mathrm{q}=$ quartet, sept $=$ septet, ov $\mathrm{dd}=$ overlapping doublet of doublets, and $\mathrm{m}$ $=$ multiplet. All coupling constants are absolute values and are expressed in Hertz $(\mathrm{Hz})$. IR spectra were measured on a Shimadzu IR Affinity-1 photospectrometer. The description of signals includes $\mathrm{s}=$ strong, $\mathrm{m}=$ medium, $\mathrm{w}=$ weak, $\mathrm{sh}=$ shoulder, and $\mathrm{br}=$ broad. Mass spectra were measured by the School of Chemistry in Cardiff University on a Waters LCT Premier/XE or a Waters GCT Premier spectrometer. Elemental analysis was performed by Dr. Nigel Howard at Cambridge University.

Note 1: Caution! The aluminum compounds prepared in this manuscript are potentially shock and thermally sensitive due to the potential formation of benzyne intermediates. Appropriate care should be taken.

Note 2: Due to the potential for benzyne formation, lack of inhouse elemental analysis (EA) facilities, and the closure of our laboratory as well as the external EA facilities due to the COVID-19 pandemic, elemental analysis of some of the compounds was not performed.

General Procedure 1. The triarylboranes were synthesized in a procedure adapted from Lancaster ${ }^{28}$ whereby magnesium turnings (1.0 equiv) were suspended in diethyl ether $(50 \mathrm{~mL})$. The appropriate bromobenzene (1.0 equiv) was slowly added dropwise, and an ice bath was added to ensure that the reaction did not reflux. 1,2Dibromoethane was added if the Grignard reaction was slow to initiate. After it stirred at ambient temperature for $1 \mathrm{~h}$, the mixture was transferred via filter cannula to a stirred solution of $\mathrm{BF}_{3} \cdot \mathrm{OEt}_{2}$ ( 0.33 equiv) in toluene $(30 \mathrm{~mL})$. The diethyl ether solvent was removed in vacuo, and the resulting toluene solution was heated to reflux for $3 \mathrm{~h}$. After this time the reaction was allowed to stir for $16 \mathrm{~h}$ at ambient temperature, after which the solvent was removed in vacuo. The resulting solid was subjected to a 2 -fold sublimation $\left(120^{\circ} \mathrm{C}, 1 \times\right.$ $\left.10^{-3} \mathrm{mbar}\right)$, whereupon the pure borane was collected as a white crystalline solid.

Synthesis of Tris(3,4,5-trifluorophenyl)borane (1). Tris(3,4,5trifluorophenyl)borane was synthesized according to general procedure 1, using magnesium turnings $(3.0 \mathrm{~g}, 0.125 \mathrm{~mol}, 1.0$ equiv), 5-bromo-1,2,3-trifluorobenzene $(14.9 \mathrm{~mL}, 0.125 \mathrm{~mol}, 1.0$ equiv), and $\mathrm{BF}_{3} \cdot \mathrm{OEt}_{2}(5.1 \mathrm{~mL}, 42 \mathrm{mmol}, 0.33$ equiv). Yield: $2.70 \mathrm{~g}$, $6.67 \mathrm{mmol}, 16 \%$. Spectroscopic analyses agree with literature values. ${ }^{22}$ ${ }^{1} \mathrm{H}$ NMR (500 MHz, $\left.\mathrm{CDCl}_{3}, 295 \mathrm{~K}\right) \delta / \mathrm{ppm}$ : 7.19-7.16 (m, 6H, Ar$\mathrm{H}) .{ }^{13} \mathrm{C}\left\{{ }^{1} \mathrm{H}\right\}$ NMR $\left(126 \mathrm{MHz}, \mathrm{C}_{6} \mathrm{D}_{6}, 295 \mathrm{~K}\right) \delta / \mathrm{ppm}: 152.3-150.2$ (m, 6C, Ar), 144.2-141.9 (m, 3C, Ar), 136.4 (3C, C-B), 122.8$121.2(\mathrm{~m}, 6 \mathrm{C}, \mathrm{Ar}) .{ }^{11} \mathrm{~B}\left\{{ }^{1} \mathrm{H}\right\} \mathrm{NMR}\left(160 \mathrm{MHz}, \mathrm{CDCl}_{3}, 295 \mathrm{~K}\right) \delta / \mathrm{ppm}$ : $64.5(\mathrm{~s}) .{ }^{19} \mathrm{~F}$ NMR $\left(471 \mathrm{MHz}, \mathrm{CDCl}_{3}, 295 \mathrm{~K}\right) \delta / \mathrm{ppm}:-133.3(\mathrm{dd}$, $\left.{ }^{3} J_{\mathrm{FF}}=20.0 \mathrm{~Hz},{ }^{3} J_{\mathrm{FH}}=7.2 \mathrm{~Hz}, 6 \mathrm{~F}, m \mathrm{~F}\right),-158.2\left(\mathrm{tt},{ }^{3} J_{\mathrm{FF}}=20.0 \mathrm{~Hz},{ }^{4} J_{\mathrm{FH}}\right.$ $=6.8 \mathrm{~Hz}, 3 \mathrm{~F}, p \mathrm{~F})$. EA calcd for $\mathrm{C}_{18} \mathrm{H}_{6} \mathrm{BF}_{9}: \mathrm{C}, 53.51 ; \mathrm{H}, 1.50 ; \mathrm{N}, 0.00$. Found: C, 53.27; H, 1.41; N, 0.00 .

Synthesis of Tris(2,3,4-trifluorophenyl)borane (3). Tris(2,3,4trifluorophenyl)borane was synthesized according to general procedure 1 , using magnesium turnings $(0.49 \mathrm{~g}, 20 \mathrm{mmol}, 1.0$ equiv), 5-bromo-1,2,3-trifluorobenzene ( $2.4 \mathrm{~mL}, 20 \mathrm{mmol}, 1.0$ equiv), and $\mathrm{BF}_{3} \cdot \mathrm{OEt}_{2}(0.8 \mathrm{~mL}, 6.7 \mathrm{mmol}, 0.33$ equiv). Yield: $0.38 \mathrm{~g}, 0.93$ mmol, 14\%. ${ }^{1} \mathrm{H}$ NMR (400 MHz, $\left.\mathrm{C}_{6} \mathrm{D}_{6}, 295 \mathrm{~K}\right) \delta / \mathrm{ppm}: 6.43-6.38$ $(\mathrm{m}, 6 \mathrm{H}, \mathrm{Ar}-\mathrm{H}) .{ }^{13} \mathrm{C}\left\{{ }^{1} \mathrm{H}\right\} \mathrm{NMR}\left(126 \mathrm{MHz}, \mathrm{C}_{6} \mathrm{D}_{6}, 295 \mathrm{~K}\right) \delta / \mathrm{ppm}$ : 156.8-156.0 (m, 3C, Ar), 154.2-153.5 (m, 3C, Ar), 141.6-141.3 (m, 3C, Ar), 139.1-138.8 (m, 3C, Ar), $132.3\left(\mathrm{dd},{ }^{2} J_{\mathrm{FC}}=12.9 \mathrm{~Hz},{ }^{3} J_{\mathrm{FC}}\right.$ $=7.7 \mathrm{~Hz}, 3 \mathrm{C}), 112.8\left(\mathrm{dd},{ }^{2} J_{\mathrm{FC}}=16.7 \mathrm{~Hz},{ }^{3} J_{\mathrm{FC}}=3.1 \mathrm{~Hz}, 3 \mathrm{C}\right) .{ }^{11} \mathrm{~B}\left\{{ }^{1} \mathrm{H}\right\}$ NMR (128 MHz, $\left.\mathrm{C}_{6} \mathrm{D}_{6}, 295 \mathrm{~K}\right) \delta / \mathrm{ppm}: 62.6(\mathrm{~s}) .{ }^{19} \mathrm{~F}\left\{{ }^{1} \mathrm{H}\right\}$ NMR $(376$ $\left.\mathrm{MHz}, \mathrm{C}_{6} \mathrm{D}_{6}, 295 \mathrm{~K}\right) \delta / \mathrm{ppm}:-121.6\left(\mathrm{dd},{ }^{3} J_{\mathrm{FF}}=20.9 \mathrm{~Hz},{ }^{4} J_{\mathrm{FF}}=12.4\right.$ $\mathrm{Hz}, 3 \mathrm{~F}),-126.0\left(\mathrm{dd},{ }^{3} J_{\mathrm{FF}}=20.9 \mathrm{~Hz},{ }^{4} J_{\mathrm{FF}}=12.4 \mathrm{~Hz}, 3 \mathrm{~F}\right),-160.8(\mathrm{t}$, $\left.{ }^{3} J_{\mathrm{FF}}=20.9 \mathrm{~Hz}, 3 \mathrm{~F}\right)$. HRMS $\left(\mathrm{EI}^{+}\right)[\mathrm{M}]^{+}\left[\mathrm{C}_{18} \mathrm{H}_{6} \mathrm{BF}_{9}\right]^{+}$: calcd 404.0419; found, 404.0410. EA calcd for $\mathrm{C}_{18} \mathrm{H}_{6} \mathrm{BF}_{9}$ : C, 53.51; H, 1.50; N, 0.00 . Found: C, 53.31; H, 1.51; N, 0.00 .

General Procedure 2. The parent borane (1.0 equiv) was suspended in hexane $(3 \mathrm{~mL})$. To this, trimethylaluminum (1.0 equiv) was added dropwise and the reaction was left undisturbed for 4 days. During this time, crystals of the alane were developed. The solvent level was reduced by removal in vacuo and placed in the freezer at -40 ${ }^{\circ} \mathrm{C}$ to ensure all the product had crystallized out. The hexane solvent was removed via pipet, and the crystals were briefly dried in vacuo to give the product.

Synthesis of $\mu_{2}$-Dimethyl-bis[(3,4,5-trifluorophenyl)methylalane] (2). Caution! This compound is potentially shock and thermally sensitive; appropriate care should be taken.

$\mu_{2}$-Dimethyl-bis[(3,4,5-trifluorophenyl)methyl-alane $]$ was synthesized in accordance with general procedure 2, using tris(3,4,5trifluorophenyl)borane $(210 \mathrm{mg}, 0.51 \mathrm{mmol}, 1.0$ equiv) and trimethylaluminum $(0.25 \mathrm{~mL}, 0.51 \mathrm{mmol}, 1.0$ equiv, $2.0 \mathrm{M}$ solution in hexanes). Yield: $158 \mathrm{mg}, 0.42 \mathrm{mmol}, 83 \%$. Mp: $105-110{ }^{\circ} \mathrm{C} .{ }^{1} \mathrm{H}$ NMR $\left(500 \mathrm{MHz}, \mathrm{C}_{6} \mathrm{D}_{6}, 295 \mathrm{~K}\right) \delta / \mathrm{ppm}: 6.87$ (ov dd, $J=7.0 \mathrm{~Hz}, 4 \mathrm{H}$, $\mathrm{Ar}-\mathrm{H}),-0.39\left(\mathrm{~s}, 12 \mathrm{H}, \mathrm{CH}_{3}\right) .{ }^{13} \mathrm{C}\left\{{ }^{1} \mathrm{H}\right\}$ NMR $\left(126 \mathrm{MHz}, \mathrm{C}_{6} \mathrm{D}_{6}, 295\right.$ K) $\delta / \mathrm{ppm}: 151.5\left(\mathrm{ddd},{ }^{1} J_{\mathrm{FC}}=256 \mathrm{~Hz},{ }^{2} J_{\mathrm{FC}}=12.3 \mathrm{~Hz},{ }^{3} J_{\mathrm{FC}}=1.6 \mathrm{~Hz}\right.$, $4 \mathrm{C}, m \mathrm{C}), 141.4\left(\mathrm{dt},{ }^{1} \mathrm{~J}_{\mathrm{FC}}=254 \mathrm{~Hz},{ }^{2} \mathrm{~J}_{\mathrm{FC}}=12.3 \mathrm{~Hz}, 2 \mathrm{C}, p \mathrm{C}\right), 138.5$ (2C, C-Al), $121.9\left(\mathrm{dd},{ }^{2} J_{\mathrm{FC}}=11.6 \mathrm{~Hz},{ }^{3} J_{\mathrm{FC}}=3.0 \mathrm{~Hz}, 6 \mathrm{C}, o \mathrm{C}\right),-7.9$ $\left(4 \mathrm{C}, \mathrm{CH}_{3}\right) .{ }^{19} \mathrm{~F}$ NMR $\left(376 \mathrm{MHz}, \mathrm{C}_{6} \mathrm{D}_{6}, 295 \mathrm{~K}\right) \delta / \mathrm{ppm}:-135.3(\mathrm{dd}$, $\left.{ }^{3} J_{\mathrm{FF}}=19.8 \mathrm{~Hz},{ }^{3} J_{\mathrm{FH}}=5.8 \mathrm{~Hz}, 4 \mathrm{~F}, m \mathrm{~F}\right),-158.2(\mathrm{~s}, 2 \mathrm{~F}, p \mathrm{~F})$. IR $\nu_{\max }$ $\left(\mathrm{cm}^{-1}\right)$ : $1516(\mathrm{~m}), 1387(\mathrm{~m}), 1302(\mathrm{~m}), 1198(\mathrm{w}), 1088(\mathrm{~m}), 1030$ $(\mathrm{m}), 878(\mathrm{~m}), 849(\mathrm{~m}), 654(\mathrm{br}, \mathrm{m}), 579(\mathrm{br}, \mathrm{m})$. Note: approximately $8 \%$ impurity was observed in the ${ }^{19} \mathrm{~F}$ NMR spectrum due to the parent borane and other unidentified partially transmetalated species.

Synthesis of Tris(2,3,4-trifluorophenyl)alane (4). Caution! This compound is potentially shock and thermally sensitive; appropriate care should be taken.

Tris(2,3,4-trifluorophenyl)alane was synthesized in accordance with general procedure 2, using tris(2,3,4-trifluorophenyl)borane (300 mg, $0.74 \mathrm{mmol}, 1.0$ equiv), and trimethylaluminum $(0.37 \mathrm{~mL}$, $0.74 \mathrm{mmol}, 1.0$ equiv, $2.0 \mathrm{M}$ solution in hexanes). Yield: $243 \mathrm{mg}, 0.58$ $\mathrm{mmol}, 78 \%$. Crystals suitable for single-crystal X-ray diffraction were collected from the hexane solution. Mp: $145-147{ }^{\circ} \mathrm{C} .{ }^{1} \mathrm{H}$ NMR (400 $\left.\mathrm{MHz}, \mathrm{C}_{6} \mathrm{D}_{6}, 295 \mathrm{~K}\right) \delta / \mathrm{ppm}: 6.74(\mathrm{br} \mathrm{s}, 3 \mathrm{H}, \mathrm{Ar}-\mathrm{H}), 6.53\left(\mathrm{dd},{ }^{3} J_{\mathrm{FH}}=\right.$ $\left.14.8 \mathrm{~Hz},{ }^{3} \mathrm{~J}_{\mathrm{HH}}=8.5 \mathrm{~Hz}, 3 \mathrm{H}, \mathrm{Ar}-\mathrm{H}\right) .{ }^{13} \mathrm{C}\left\{{ }^{1} \mathrm{H}\right\} \operatorname{NMR}\left(126 \mathrm{MHz}, \mathrm{C}_{6} \mathrm{D}_{6}\right.$, $295 \mathrm{~K}) \delta / \mathrm{ppm}: 156.9\left(\mathrm{~d},{ }^{1} J_{\mathrm{FC}}=235 \mathrm{~Hz}, 3 \mathrm{C}, \mathrm{Ar}\right), 152.8\left(\mathrm{~d},{ }^{1} J_{\mathrm{FC}}=252\right.$ $\mathrm{Hz}, 3 \mathrm{C}, \mathrm{Ar}), 139.4\left(\mathrm{ddd},{ }^{1} J_{\mathrm{FC}}=255 \mathrm{~Hz},{ }^{2} J_{\mathrm{FC}}=21.4 \mathrm{~Hz},{ }^{2} J_{\mathrm{FC}}=14.7\right.$ $\mathrm{Hz}, 3 \mathrm{C}, \mathrm{Ar}$ ), 132.1 (s, 1C, Ar), 130.7 (s, 1C, Ar), 113.5 (d, ${ }^{2} J_{\mathrm{FC}}=14.9$ $\mathrm{Hz}, 3 \mathrm{C}, \mathrm{Ar}) .{ }^{19} \mathrm{~F}$ NMR $\left(376 \mathrm{MHz}, \mathrm{C}_{6} \mathrm{D}_{6}, 295 \mathrm{~K}\right) \delta / \mathrm{ppm}:-115.1(\mathrm{~s}$, 3F, $\mathrm{Ar}-\mathrm{F}$ ), -132.9 (s, 3F, $\mathrm{Ar}-\mathrm{F})-162.1$ to -162.2 (m, 3F, Ar-F). HRMS $\left(\mathrm{ES}^{+}\right):[\mathrm{M}]^{+}\left[\mathrm{C}_{18} \mathrm{H}_{6} \mathrm{AlF}_{9}\right]^{+}$: calcd 420.0141; found 419.3153 . EA calcd for $\mathrm{C}_{18} \mathrm{H}_{6} \mathrm{AlF}_{9}$ : C, 51.45; H, 1.44; N, 0.00. Found: C, 51.49; $\mathrm{H}, 1.43 ; \mathrm{N}, 0.00$.

Characterization of Tris(2,3,4-trifluorophenyl)alane.THF (4.THF). ${ }^{1} \mathrm{H}$ NMR (400 MHz, $\left.\mathrm{CDCl}_{3}, 295 \mathrm{~K}\right) \delta / \mathrm{ppm}: 7.10-7.00(\mathrm{~m}, 3 \mathrm{H}, \mathrm{Ar}-$ $\mathrm{H}), 6.99-6.88(\mathrm{~m}, 3 \mathrm{H}, \mathrm{Ar}-\mathrm{H}), 4.39(\mathrm{~s}, 6 \mathrm{H}, \mathrm{THF}), 2.64-2.13(\mathrm{~m}$, $6 \mathrm{H}, \mathrm{THF}) .{ }^{13} \mathrm{C}\left\{{ }^{1} \mathrm{H}\right\}$ NMR $\left(101 \mathrm{MHz}, \mathrm{CDCl}_{3}, 295 \mathrm{~K}\right) \delta / \mathrm{ppm}: 156.5$ $\left(\mathrm{ddd},{ }^{1} J_{\mathrm{FC}}=232.6 \mathrm{~Hz},{ }^{2} J_{\mathrm{FC}}=6.6 \mathrm{~Hz},{ }^{3} J_{\mathrm{FC}}=2.9 \mathrm{~Hz}, 3 \mathrm{C}, o \mathrm{C}-\mathrm{F}\right), 152.2$ (ddd, ${ }^{1} J_{\mathrm{FC}}=249.5 \mathrm{~Hz},{ }^{2} J_{\mathrm{FC}}=10.0 \mathrm{~Hz},{ }^{3} J_{\mathrm{FC}}=3.9 \mathrm{~Hz}, 3 \mathrm{C}, p \mathrm{C}$ ), 139.4 $\left(\mathrm{ddd},{ }^{1} J_{\mathrm{FC}}=253.9 \mathrm{~Hz},{ }^{2} J_{\mathrm{FC}}=22.3 \mathrm{~Hz},{ }^{2} J_{\mathrm{FC}}=14.4 \mathrm{~Hz}, 3 \mathrm{C}, m \mathrm{C}-\mathrm{F}\right)$, $132.5-132.2(\mathrm{~m}, 3 \mathrm{C}, o \mathrm{C}-\mathrm{H}), 126.2\left(\mathrm{~d},{ }^{2} J_{\mathrm{FC}}=51.5 \mathrm{~Hz}, 3 \mathrm{C}, i \mathrm{C}\right)$, $113.4\left(\mathrm{~d},{ }^{2} J_{\mathrm{FC}}=15.5 \mathrm{~Hz}, 3 \mathrm{C}, m \mathrm{C}-\mathrm{H}\right), 74.0(\mathrm{~s}, 4 \mathrm{C}, \mathrm{THF}), 25.7(\mathrm{~s}, 4 \mathrm{C}$, 
THF). ${ }^{19} \mathrm{~F}$ NMR $\left(376 \mathrm{MHz}, \mathrm{CDCl}_{3}, 295 \mathrm{~K}\right) \delta / \mathrm{ppm}:-117.89$ (dd, $\left.{ }^{3} J_{\mathrm{FF}}=26.9 \mathrm{~Hz},{ }^{4} J_{\mathrm{FF}}=8.3 \mathrm{~Hz}, 3 \mathrm{~F}, p \mathrm{~F}\right),-135.21\left(\mathrm{dd},{ }^{3} J_{\mathrm{FF}}=19.1 \mathrm{~Hz}\right.$, $\left.{ }^{4} J_{\mathrm{FF}}=8.3 \mathrm{~Hz}, 3 \mathrm{~F}, o \mathrm{~F}\right),-163.21\left(\mathrm{dd},{ }^{3} J_{\mathrm{FF}}=26.9 \mathrm{~Hz},{ }^{4} J_{\mathrm{FF}}=19.1 \mathrm{~Hz}\right.$, $3 \mathrm{~F}, m \mathrm{~F}$ ).

Synthesis of Tris(3,4,5-trifluorophenyl)alane etherate (5). Caution! This compound is potentially shock and thermally sensitive; appropriate care should be taken.

In an ice bath, a Grignard solution was prepared by adding magnesium turnings ( $486 \mathrm{mg}, 20 \mathrm{mmol}, 1.0$ equiv) to 5-bromo-1,2,3trifluorobenzene $(2.4 \mathrm{~mL}, 20 \mathrm{mmol}, 1.0$ equiv) in diethyl ether $(20$ $\mathrm{mL})$. 1,2-Dibromoethane $(0.5 \mathrm{~mL})$ was added dropwise to initiate the reaction. Once the reaction had initiated the ice bath was removed and the reaction was left to stir at ambient temperature for $1 \mathrm{~h}$. Note that if the Grignard solution starts to reflux, it needs to be placed back in the ice bath. During this time a three-necked flask equipped with a reflux condenser was set up and degassed. Aluminum trichloride (888 $\mathrm{mg}, 6.7 \mathrm{mmol}, 0.33$ equiv) and toluene $(20 \mathrm{~mL}$ ) was added to the three-necked flask. An ice bath was added to the three-necked flask, and the Grignard solution was transferred to the mixture via filter cannula. The resulting reaction was allowed to warm to room temperature, after which the ether solvent was removed in vacuo. The toluene solution was heated to reflux for $3 \mathrm{~h}$, during which time the reaction turned golden yellow and a precipitate formed. The reaction was then cooled to ambient temperature; the reflux condenser was removed (a glass stopper added), and then the mixture was stirred at ambient temperature for a further $16 \mathrm{~h}$. After this, the solution was filtered via a filter cannula and the toluene solvent was removed in vacuo. The resulting solid was washed with pentane and dried in vacuo to give the etherate product tris(3,4,5-trifluorophenyl)alane as an offwhite powder ( $1.58 \mathrm{~g}, 3.2 \mathrm{mmol}, 48 \%)$. Crystals suitable for singlecrystal X-ray diffraction were grown from a saturated solution of toluene with a few drops of pentane added and cooled to $-40{ }^{\circ} \mathrm{C}$. Due to the potential for benzyne formation, the product was not sublimed. Mp: $126-134{ }^{\circ} \mathrm{C} .{ }^{1} \mathrm{H}$ NMR $\left(400 \mathrm{MHz}, \mathrm{C}_{6} \mathrm{D}_{6}, 295 \mathrm{~K}\right) \delta /$ ppm: 6.99 (ov dd, $J=7.0 \mathrm{~Hz}, 6 \mathrm{H}, \mathrm{Ar}-\mathrm{H}), 3.00\left(\mathrm{q},{ }^{3} J_{\mathrm{HH}}=7.0 \mathrm{~Hz}, 4 \mathrm{H}\right.$, $\left.\mathrm{CH}_{2}\right), 0.28\left(\mathrm{t},{ }^{3} J_{\mathrm{HH}}=7.0 \mathrm{~Hz}, 4 \mathrm{H}, \mathrm{CH}_{3}\right) \cdot{ }^{13} \mathrm{C}\left\{{ }^{1} \mathrm{H}\right\}$ NMR $(101 \mathrm{MHz}$, $\left.\mathrm{C}_{6} \mathrm{D}_{6}, 295 \mathrm{~K}\right) \delta / \mathrm{ppm}: 151.4\left(\mathrm{dd},{ }^{1} J_{\mathrm{FC}}=254 \mathrm{~Hz},{ }^{2} J_{\mathrm{FC}}=11.8 \mathrm{~Hz}, 6 \mathrm{C}\right.$, $m \mathrm{C}), 140.4(\mathrm{~m}, 3 \mathrm{C}, \mathrm{C}-\mathrm{Al}), 140.3\left(\mathrm{dt},{ }^{1} J_{\mathrm{FC}}=252 \mathrm{~Hz},{ }^{2} J_{\mathrm{FC}}=11.8 \mathrm{~Hz}\right.$, 3C, $p \mathrm{C}), 120.2\left(\mathrm{dd},{ }^{2} J_{\mathrm{FC}}=11.1 \mathrm{~Hz},{ }^{3} J_{\mathrm{FC}}=4.2 \mathrm{~Hz}, 6 \mathrm{C}, o \mathrm{C}\right), 68.2(\mathrm{~s}$, 2C, $\left.\mathrm{CH}_{2}\right), 12.5$ (s, 2C, $\left.\mathrm{CH}_{3}\right) .{ }^{19} \mathrm{~F}$ NMR (376 MHz, $\left.\mathrm{C}_{6} \mathrm{D}_{6}, 295 \mathrm{~K}\right) \delta /$ ppm: $-153.5\left(\mathrm{~d},{ }^{3} J_{\mathrm{FF}}=19.9 \mathrm{~Hz}, 6 \mathrm{~F}, m \mathrm{~F}\right),-160.7\left(\mathrm{t},{ }^{3} J_{\mathrm{FF}}=19.9 \mathrm{~Hz}\right.$, 3F, $p$ F). IR $\nu_{\max }\left(\mathrm{cm}^{-1}\right): 1601(\mathrm{~m}), 1512(\mathrm{~s}), 1387(\mathrm{~s}), 1302(\mathrm{~s})$, $1267(\mathrm{w}), 1223(\mathrm{w}), 1190(\mathrm{w}), 1148(\mathrm{w}), 1088(\mathrm{~s}), 1028(\mathrm{~s}), 1015$ $(\mathrm{s}), 887(\mathrm{~m}), 878(\mathrm{~m}), 849(\mathrm{~s}), 772(\mathrm{~m}), 745(\mathrm{~m}), 710(\mathrm{~m}), 600(\mathrm{~s})$, 584 (s), 519 (s), 503 (sh). HRMS (EI $)\left[\mathrm{M}-O E t_{2}\right]^{+}\left[\mathrm{C}_{18} \mathrm{H}_{6} \mathrm{AlF}_{9}\right]^{+}$: calcd 420.0141; found 419.1153.

General Procedure 3. In accordance with the literature known procedure, ${ }^{3}$ the necessary aldehyde $(10 \mathrm{mmol})$ was dissolved in $\mathrm{CH}_{2} \mathrm{Cl}_{2}(10 \mathrm{~mL})$ along with $3 \AA$ molecular sieves. To this, the required amine $(10 \mathrm{mmol})$ was added. The reaction was left at ambient temperature for $2 \mathrm{~h}$, at which point $\mathrm{MgSO}_{4}$ was added with subsequent filtration. Volatiles were removed in vacuo to leave the pure imine in quantitative yields. Full synthetic procedures and characterization for each imine can be found in the Supporting Information.

General Procedure 4. In an NMR tube, pinacol borane ( $35 \mu \mathrm{L}$, $240 \mu \mathrm{mol}, 1.2$ equiv) and the substrate $(200 \mu \mathrm{mol}, 1.0$ equiv $)$ were combined in deuterated chloroform $(0.7 \mathrm{~mL})$. To this, tris $(3,4,5-$ trifluorophenyl)alane etherate $(10 \mathrm{mg}, 20 \mu \mathrm{mol}, 0.1$ equiv) was added, and the NMR tube was sealed. The mixture was heated to 70 ${ }^{\circ} \mathrm{C}$, and conversion was monitored via in situ ${ }^{1} \mathrm{H}$ NMR spectroscopy until the desired boronate ester had been formed in $>95 \%$ yield. Upon completion of the reaction, the catalyst was removed (and for compounds $\mathbf{6}-\mathbf{8}$, the boronate ester was hydrolyzed) by washing with $1 \mathrm{M} \mathrm{NaOH}(3 \times 10 \mathrm{~mL})$ and was further purified using flash column chromatography. Full synthetic procedures and characterization for each reduction product can be found in the Supporting Information.

\section{CONCLUSIONS}

In conclusion, we have reported the synthesis of $\mathrm{Al}(3,4,5$ $\left.\mathrm{Ar}^{\mathrm{F}}\right)_{3} \cdot \mathrm{Et}_{2} \mathrm{O}$, which was prepared from the corresponding Grignard solution. Attempts to synthesize the triarylalane from transmetalation resulted in the formation of the bridging dimer $\mu_{2}-\mathrm{Al}\left(3,4,5-\mathrm{Ar}^{\mathrm{F}}\right) \mathrm{Me}_{2}$. On the other hand, the synthesis of the novel triarylalane $\mathrm{Al}\left(2,3,4-\mathrm{Ar}^{\mathrm{F}}\right)_{3}$ proceeded smoothly from the parent borane $\mathrm{B}\left(2,3,4-\mathrm{Ar}^{\mathrm{F}}\right)_{3}$. The solid-state structures of these compounds were obtained, and $\mathrm{Al}(2,3,4-$ $\left.\mathrm{Ar}^{\mathrm{F}}\right)_{3}$ was found to form an extended chain structure via $\mathrm{Al} \cdots \mathrm{F}$ strong contacts. Lastly, $\mathrm{Al}\left(3,4,5-\mathrm{Ar}^{\mathrm{F}}\right)_{3} \cdot \mathrm{Et}_{2} \mathrm{O}$ was found to be an efficient catalyst for hydroboration reduction, with wide tolerance toward carbonyls, imines, and alkynes. Further studies are underway in our laboratory to explore the full potential of these triarylalanes in catalysis.

\section{ASSOCIATED CONTENT}

\section{(s) Supporting Information}

The Supporting Information is available free of charge at https://pubs.acs.org/doi/10.1021/acs.inorgchem.0c01076.

Catalysis information, NMR spectra, XRD data, and DFT calculations (PDF)

\section{Accession Codes}

CCDC 1996144-1996147 and 2022498 contain the supplementary crystallographic data for this paper. These data can be obtained free of charge via www.ccdc.cam.ac.uk/data request/ cif, or by emailing data_request@ccdc.cam.ac.uk, or by contacting The Cambridge Crystallographic Data Centre, 12 Union Road, Cambridge CB2 1EZ, UK; fax: +44 1223336033.

\section{AUTHOR INFORMATION}

\section{Corresponding Author}

Rebecca L. Melen - Cardiff Catalysis Institute, School of Chemistry, Cardiff University, Cardiff CF10 3AT, Cymru/ Wales, U.K.; $\odot$ orcid.org/0000-0003-3142-2831; Email: MelenR@cardiff.ac.uk

\section{Authors}

Darren M. C. Ould - Cardiff Catalysis Institute, School of Chemistry, Cardiff University, Cardiff CF10 3AT, Cymru/ Wales, U.K.

Jamie L. Carden - Cardiff Catalysis Institute, School of Chemistry, Cardiff University, Cardiff CF10 3AT, Cymru/ Wales, U.K.

Rowan Page - Cardiff Catalysis Institute, School of Chemistry, Cardiff University, Cardiff CF10 3AT, Cymru/Wales, U.K.

Complete contact information is available at:

https://pubs.acs.org/10.1021/acs.inorgchem.0c01076

\section{Author Contributions}

† These authors contributed equally to this work.

\section{Notes}

The authors declare no competing financial interest.

Information about the data that underpins the results presented in this article, including how to access them, can be found in the Cardiff University data catalogue at http://doi. org/10.17035/d.2020.0114501208.

\section{ACKNOWLEDGMENTS}

R.L.M. would like to acknowledge the EPSRC for an Early Career Fellowship for funding (EP/R026912/1). J.L.C. would 
like to acknowledge the EPSRC for funding (EP/L016443/1). D.M.C.O. would like to acknowledge Professor Jeremy M. Rawson (University of Windsor) for assistance with refinement of X-ray structures.

\section{REFERENCES}

(1) Welch, G. C.; Juan, R. R. S.; Masuda, J. D.; Stephan, D. W. Reversible, Metal-Free Hydrogen Activation. Science 2006, 314, $1124-1126$.

(2) Lawson, J. R.; Melen, R. L. Tris(Pentafluorophenyl)Borane and Beyond: Modern Advances in Borylation Chemistry. Inorg. Chem. 2017, 56, 8627-8643.

(3) Carden, J. L.; Dasgupta, A.; Melen, R. L. Halogenated Triarylboranes: Synthesis, Properties and Applications in Catalysis. Chem. Soc. Rev. 2020, 49, 1706-1725.

(4) Pohlmann, J. L. W.; Brinckmann, F. E. Preparation and Characterization of Group III A Derivatives. Z. Naturforsch., B: J. Chem. Sci. 1965, 20b, 5-11.

(5) Belgardt, T.; Storre, J.; Roesky, H. W.; Noltemeyer, M.; Schmidt, H.-G. Tris(Pentafluorophenyl)Alane: A Novel Aluminum Organyl. Inorg. Chem. 1995, 34, 3821-3822.

(6) Lee, C. H.; Lee, S. J.; Park, J. W.; Kim, K. H.; Lee, B. Y.; Oh, J. S. Preparation of $\mathrm{Al}\left(\mathrm{C}_{6} \mathrm{~F}_{5}\right)_{3}$ and Its Use for the Modification of Methylalumoxane. J. Mol. Catal. A: Chem. 1998, 132, 231-239.

(7) Stahl, N. G.; Salata, M. R.; Marks, T. J. B $\left(\mathrm{C}_{6} \mathrm{~F}_{5}\right)_{3}$ - vs $\mathrm{Al}\left(\mathrm{C}_{6} \mathrm{~F}_{5}\right)_{3}$ Derived Metallocenium Ion Pairs. Structural, Thermochemical, and Structural Dynamic Divergences. J. Am. Chem. Soc. 2005, 127, 10898-10909.

(8) Feng, S.; Roof, G. R.; Chen, E. Y.-X. Tantalum(V)-Based Metallocene, Half-Metallocene, and Non-Metallocene Complexes as Ethylene-1-Octene Copolymerization and Methyl Methacrylate Polymerization Catalysts. Organometallics 2002, 21, 832-839.

(9) Timoshkin, A. Y.; Frenking, G. Gas-Phase Lewis Acidity of Perfluoroaryl Derivatives of Group 13 Elements. Organometallics 2008, 27, 371-380.

(10) Chen, J.; Chen, E. Y. X. Elusive Silane-Alane Complex [Si-H $\cdots$ Al]: Isolation, Characterization, and Multifaceted Frustrated Lewis Pair Type Catalysis. Angew. Chem., Int. Ed. 2015, 54, 6842-6846.

(11) Chen, J.; Chen, E. Y. X. Unsolvated $\mathrm{Al}\left(\mathrm{C}_{6} \mathrm{~F}_{5}\right)_{3}$ : Structural Features and Electronic Interaction with Ferrocene. Dalton Trans. 2016, 45, 6105-6110.

(12) Hu, L.; He, J.; Zhang, Y.; Chen, E. Y. X. Living Group Transfer Polymerization of Renewable $\alpha$-Methylene- $\gamma$-Butyrolactones Using $\mathrm{Al}\left(\mathrm{C}_{6} \mathrm{~F}_{5}\right)_{3}$ Catalyst. Macromolecules 2018, 51, 1296-1307.

(13) Ménard, G.; Stephan, D. W. $\mathrm{H}_{2}$ Activation and Hydride Transfer to Olefins by $\operatorname{Al}\left(\mathrm{C}_{6} \mathrm{~F}_{5}\right)_{3}$-Based Frustrated Lewis Pairs. Angew. Chem., Int. Ed. 2012, 51, 8272-8275.

(14) Ménard, G.; Stephan, D. W. C-H Activation of Isobutylene Using Frustrated Lewis Pairs: Aluminum and Boron $\sigma$-Allyl Complexes. Angew. Chem., Int. Ed. 2012, 51, 4409-4412.

(15) Ménard, G.; Hatnean, J. A.; Cowley, H. J.; Lough, A. J.; Rawson, J. M.; Stephan, D. W. C-H Bond Activation by Radical Ion Pairs Derived from $\mathrm{R}_{3} \mathrm{P} / \mathrm{Al}\left(\mathrm{C}_{6} \mathrm{~F}_{5}\right)_{3}$ Frustrated Lewis Pairs and $\mathrm{N} 2 \mathrm{O}$. J. Am. Chem. Soc. 2013, 135, 6446-6449.

(16) Ménard, G.; Gilbert, T. M.; Hatnean, J. A.; Kraft, A.; Krossing, I.; Stephan, D. W. Stoichiometric Reduction of $\mathrm{CO}_{2}$ to $\mathrm{CO}$ by Phosphine/AlX 3-Based Frustrated Lewis Pairs. Organometallics 2013, $32,4416-4422$

(17) Ménard, G.; Tran, L.; Stephan, D. W. Activation of $\mathrm{H}_{2}$ Using $\mathrm{P} / \mathrm{Al}$ Based Frustrated Lewis Pairs and Reactions with Olefins. Dalton Trans. 2013, 42, 13685-13691.

(18) Sato, S.; Takeda, N.; Ueda, M.; Miyata, O. Sequential [3,3]Sigmatropic Rearrangement/Nucleophilic Arylation of $\mathrm{N}$ -(Benzoyloxy)Enamides towards the Preparation of Cyclic $\beta$-Aryl- $\beta$ Amino Alcohols. Synthesis 2016, 48, 882-892.

(19) Miyoshi, T.; Matsuya, S.; Tsugawa, M.; Sato, S.; Ueda, M.; Miyata, O. Sequential Retro-Ene Arylation Reaction of N-
Alkoxyenamides for the Synthesis of Tert -Alkylamines. Org. Lett. 2013, 15, 3374-3377.

(20) Yin, Q.; Soltani, Y.; Melen, R. L.; Oestreich, M. BAr ${ }^{F^{-}}$ Catalyzed Imine Hydroboration with Pinacolborane Not Requiring the Assistance of an Additional Lewis Base. Organometallics 2017, 36, 2381-2384.

(21) Santi, M.; Ould, D. M. C.; Wenz, J.; Soltani, Y.; Melen, R. L.; Wirth, T. Metal-Free Tandem Rearrangement/Lactonization: Access to 3,3-Disubstituted Benzofuran-2-(3H)-Ones. Angew. Chem., Int. Ed. 2019, 58, 7861-7865.

(22) Carden, J. L.; Gierlichs, L. J.; Wass, D. F.; Browne, D. L.; Melen, R. L. Unlocking the Catalytic Potential of Tris(3,4,5Trifluorophenyl)Borane with Microwave Irradiation. Chem. Commun. 2019, 55, 318-321.

(23) Stammler, H.; Blomeyer, S.; Berger, R. J. F.; Mitzel, N. W. Trimethylaluminum: Bonding by Charge and Current Topology. Angew. Chem., Int. Ed. 2015, 54, 13816-13820.

(24) Klosin, J.; Roof, G. R.; Chen, E. Y. X.; Abboud, K. A. Ligand Exchange and Alkyl Abstraction Involving (Perfluoroaryl)Boranes and Alanes with Aluminum and Gallium Alkyls. Organometallics 2000, 19, 4684-4686.

(25) Christe, K. O.; Dixon, D. A.; McLemore, D.; Wilson, W. W.; Sheehy, J. A.; Boatz, J. A. On a Quantitative Scale for Lewis Acidity and Recent Progress in Polynitrogen Chemistry. J. Fluorine Chem. 2000, 101, 151-153.

(26) Körte, L. A.; Schwabedissen, J.; Soffner, M.; Blomeyer, S.; Reuter, C. G.; Vishnevskiy, Y. V.; Neumann, B.; Stammler, H. G.; Mitzel, N. W. Tris(Perfluorotolyl)Borane-A Boron Lewis Superacid. Angew. Chem., Int. Ed. 2017, 56, 8578-8582.

(27) Böhrer, H.; Trapp, N.; Himmel, D.; Schleep, M.; Krossing, I. From Unsuccessful $\mathrm{H}_{2}$-Activation with FLPs Containing B(Ohfip) ${ }_{3}$ to a Systematic Evaluation of the Lewis Acidity of 33 Lewis Acids Based on Fluoride, Chloride, Hydride and Methyl Ion Affinities. Dalton Trans. 2015, 44, 7489-7499.

(28) Lancaster, D. S. Alkylation of Boron Trifluoride with Pentafluorophenyl Grignard Reagent; Tris(Pentafluorophenyl)Boron. ChemSpider SyntheticPages 2003. DOI: 10.1039/SP215. 